УДК 343.13

DOI https://doi.org/10.32844/2618-1258.2019.3-2.31

ЛУПАШКУ С.В.

\title{
ДО ПОНЯТТЯ ВІДШКОДУВАННЯ ШКОДИ У КРИМІНАЛЬНИХ ПРОВАДЖЕННЯХ У СФЕРІ ЗЕМЕЛЬНИХ ВІДНОСИН
}

Метою дослідження $є$ аналіз наукових джерел щодо особливостей визначення розміру шкоди у кримінальних провадженнях у сфері земельних відносин і формування наукової позиції щодо цього питання. У статті розглядаються особливості визначення розміру шкоди у кримінальних провадженнях у сфері земельних відносин. Дано визначення терміна «відшкодування». Зазначено, що наукове обгрунтування законодавчого закріплення певних спірних положень досліджуваного питання сприятиме реальному досягненню завдань кримінального провадження. Наголошено, що Кримінальний процесуальний кодекс (далі - КПК) України визначає порядок відшкодування шкоди у кримінальному провадженні. 3'ясовано, що порядок пред'явлення цивільного позову у кримінальному провадженні передбачений ст. 128 КПК України, яким визначено, що особа, якій кримінальним правопорушенням або іншим суспільно небезпечним діянням завдано майнової та/або моральної шкоди, має право під час кримінального провадження до початку судового розгляду пред'явити цивільний позов до підозрюваного, обвинуваченого або до фізичної чи юридичної особи, яка за законом несе цивільну відповідальність за шкоду, завдану діяннями підозрюваного, обвинуваченого або неосудної особи, що вчинила суспільно небезпечне діяння. Наголошено, що в разі завдання збитків кримінальним правопорушенням, якими спричинено шкоду інтересам неповнолітніх осіб та осіб, визнаних у встановленому законом порядку недієздатними чи обмежено дієздатними, цивільний позов може бути пред'явлений їхніми законними представниками. У разі завдання неправомірними діями збитків інтересам держави цивільний позов у кримінальному провадженні подається та підтримується прокурором. Зроблено висновок, що для представництва інтересів громадянина в суді прокурор також повинен надати документи, що підтверджують недосягнення повноліття, недієздатність або обмежену дієздатність відповідного громадянина, а також письмову згоду законного представника або органу, якому законом надано право захищати права, свободи та інтереси відповідної особи, на здійснення ним представництва.

Ключові слова: прокурор, відшкодування, розмір икоди, Кримінальний прочесуальний кодекс, досудове розслідування.

The purpose of the study is to analyze the scientific sources on the peculiarities of determining the amount of damage in criminal proceedings in the field of land relations and to formulate a scientific position on this issue. The article deals with the peculiarities of determining the amount of damage in criminal proceedings in the field of land relations. The definition of the term "compensation" is given. It is stated that the scientific substantiation of the legislative fixing of certain controversial provisions of the investigated issue will facilitate the real achievement of the tasks of criminal proceedings. It is emphasized that the Criminal Procedure Code of Ukraine determines the procedure for compensation of damages in criminal proceedings. It is established that the procedure for presenting a civil case in criminal proceedings is provided for in Art. 128 of the Criminal Procedure Code of Ukraine, which determines that a person who has been criminally violated or other socially dangerous act has caused property and/or moral damage, has the right to bring a civil action against a suspect, accused or physical or legal person during criminal proceedings before the commencement of the trial, a person who is legally liable for damage caused by the acts of a suspect, accused

(С ЛУПАШКУ С.В. - здобувач (Національна академія прокуратури України) 
or non-convicted person who committed a socially dangerous act. It is emphasized that in the case of damage caused by a criminal offense, which causes harm to the interests of minors and persons recognized in accordance with the procedure established by the law incapacitated or restricted, a legal action may be brought by their legal representatives. In the case of infliction of damage to the interests of the state, the civil action in criminal proceedings is filed and supported by the prosecutor. It is concluded that in order to represent the interests of a citizen in court, the prosecutor must also provide documents confirming the underachievement, incapacity or limited capacity of the respective citizen, as well as the written consent of the legal representative or body to whom the law has the right to protect the rights, freedoms and rights on the implementation of representation.

Key words: prosecutor, compensation, amount of damage, Criminal Procedure Code, pre-trial investigation.

Вступ. У кожному випадку під час здійснення процесуального керівництва досудовим розслідуванням у кримінальному провадженні про кримінальні правопорушення у сфері земельних відносин прокурору необхідно встановлювати суму завданих неправомірними діями збитків, джерела та засоби їх відшкодування.

Аналіз останніх досліджень і публікацій. Питання порядку визначення розміру шкоди, завданої кримінальним правопорушенням, та порядку її відшкодування досліджувались багатьма вченими-юристами й відображені у роботах, зокрема, Ю.І. Азарова, Г.А. Атанесян, Ю.П. Аленіна, Б.Т. Бєзлєпкіна, М.І. Гошковського, Ю.М. Грошевого, В.С. Зеленецького, А.Н. Іванова, Г.К. Кожевнікова, М.І. Ковальова, О.П. Кучинської, В.В. Кривобока, Е.С. Лапіна, Л.М. Лобойко, В.T. Нора, С.I. Остапенко, Д.П. Письменного, Т.І. Присяжнюка, В.В. Рожнова, С.М. Смокова, Л.Д. Удалова, В.І. Франник, О.Ю. Хабло, Л.І. Шаповалова та інших.

Постановка завдання. Метою статті $€$ аналіз наукових джерел щодо особливостей визначення розміру шкоди у кримінальних провадженнях у сфері земельних відносин і формування наукової позиції щодо цього питання.

Результати дослідження. Термін «відшкодування» за своєю сутністю означає форму відповідальності та передбачає рівнозначну компенсацію за спричинену шкоду. В теорії кримінального процесу використання зазначеного терміна «компенсація» вважається доречним, оскільки через спричинення шкоди порушуються законні права та інтереси держави чи громадянина, які надалі необхідно відновити.

Як зазначив у своїй праці В.Т. Нор, шкода, завдана кримінальним правопорушенням, проявляється у зменшенні або знищенні майнових чи немайнових (особистих) благ потерпілої особи. Характер і ступінь шкоди, завданої кримінальним правопорушенням, враховуються та впливають на застосування конкретних видів кримінальної відповідальності [10, с. 41].

Крім того, В.Т. Нор зазначив, що поняття майнової шкоди, завданої кримінальним правопорушенням, можна визначити як шкоду, заподіяну безпосередньо майну потерпілого шляхом викрадення, пошкодження або знищення, до складу якої входять як пряма шкода, спричинена будь-яким із зазначених способів, так і грошові витрати на відновлення здоров'я, а в разі смерті особи - на поховання і утримання непрацездатних членів сім’ї [10, с. 41].

Г.А. Атанесян тлумачить поняття «шкода» як категорію бухгалтерської експертизи, що зумовлено, перш за все, тим, що здебільшого завдана шкода відшкодовується в судовому порядку $[2$, c. 214$]$.

Б.Т. Безлєпкін уважає, що з погляду юридичного це «... поняття характеризується як порушення норм об'єктивного права, супроводжуване зазвичай порушенням суб'єктивних прав... », а під фактичною шкодою він розуміє «... зменшення того чи іншого майнового або немайнового блага, яке виступає конкретним об'єктом посягання (майнова і немайнова фактичні шкоди)» [3, с. 23].

M.I. Гошовський та O.I. Кучинська зазначали: «Шкода, заподіяна злочином, і шкода, що $€$ підставою для визнання особи потерпілою, має об'єктивний характер, і тому вона включається до об'єктивної сторони злочину» [5, с. 36]. Як сказав В.Т. Нор, цей об' єктивний характер проявляється й у тому, що вона, будучи заподіяна якійсь особі, існує незалежно від чиєїсь думки, зокрема й думки цієї особи. Отже, досить «... встановити хоча б в загальних рисах факт заподіяння фізичної, матеріальної чи моральної шкоди, навіть без конкретизації її ступеня тяжкості чи вираження в грошовій сумі» [10, с. 41], щоб визнати особу потерпілою від кримінального правопорушення. 
M.I. Ковальов запропонував дещо іншу класифікацію злочинних наслідків. Зокрема, науковець поділяє злочинні наслідки на: 1) матеріальні (майнова шкода або неодержані доходи); 2) фізичні (смерть людини, заподіяння шкоди іїі здоров'ю, нормальному розвиткові організму і таке інше); 3) екологічні (забруднення водойм, атмосфери, заподіяння шкоди флорі або фауні); 4) моральні (заподіяння шкоди моральному вихованню людей чи образа статусу суспільства); 5) соціальні (становлять небезпеку для державного або суспільного ладу чи для правопорядку) $[8$, c. 31].

Вдало зазначають Ю.І. Азаров, Д.П. Письменний та О.Ю. Хабло, що питання щодо забезпечення відшкодування потерпілому шкоди за кошт держави залишається дискусійним і потребує як наукового дослідження, так і законодавчого регулювання. Адже якщо добровільне відшкодування потерпілому шкоди чи їі стягнення за результатами розгляду цивільного позову знайшли своє закріплення в КПК України (статті 128, 129), то питання щодо підстав, умов і порядку відшкодування шкоди за кошт Державного бюджету України $є$ малодослідженими та потребують законодавчого закріплення у вітчизняному законодавстві [1].

Також вказані вчені у своїх роботах зазначають, що оскільки держава взяла на себе обов'язок щодо забезпечення прав і свобод людини, то й усунення наслідків вчиненого кримінального правопорушення шляхом відшкодування шкоди у тому разі, коли правоохоронні органи не справилися зі своїми функціями, держава повинна взяти на себе. А тому цілком справедливим $є$ положення, закріплене в ч. 3 ст. 127 КПК України, де визначено, що шкода, завдана потерпілому внаслідок кримінального правопорушення, компенсується йому за кошт Державного бюджету України у випадках і в порядку, передбачених законом [1].

Поява цієї норми в КПК України зумовлена також приведенням національного законодавства до міжнародно-правових стандартів. Адже 8 квітня 2005 р. Україною була підписана (але поки що не ратифікована) Європейська конвенція «Про відшкодування збитків жертвам насильницьких злочинів» (далі - Конвенція) від 24 листопада 1983 р., де в ст. 2 визначено, що коли відшкодування шкоди, завданої внаслідок умисного насильницького злочину, не може бути забезпечено з інших джерел, держава повинна взяти це на себе [6]. Окрім того, у Декларації основних принципів правосуддя для жертв злочинів і зловживань владою від 29 листопада 1985 р. вказано, що жертви злочинів мають право на найшвидшу компенсацію за заподіяну шкоду відповідно до національного законодавства. А тому Верховною Радою України було розроблено декілька законопроєктів, зокрема такі: «Про відшкодування громадянам матеріального збитку, заподіяного злочинами» від 11 вересня 2001 р., «Про відшкодування за кошт держави матеріальної шкоди фізичним особам, які потерпіли від злочину» від 27 жовтня 2010 р. Але сьогодні це питання залишається відкритим, оскільки останній законопроєкт був відправлений на доопрацювання [4, с. 210].

Отже, Ю.І. Азаров, Д.П. Письменний, О.Ю. Хабло зробили висновок, що регламентація відшкодування шкоди потерпілому у кримінальному провадженні за кошт держави потребує прийняття спеціального закону, де мають бути чітко регламентованими підстави, умови та порядок відшкодування шкоди за кошт держави. Наукове обгрунтування законодавчого закріплення певних спірних положень досліджуваного питання сприятиме реальному досягненню завдань кримінального провадження [1].

Кримінальний процесуальний кодекс України визначає порядок відшкодування шкоди у кримінальному провадженні. Зокрема, ст. 127 КПК України передбачено, що підозрюваний, обвинувачений, а також за його згодою будь-яка інша фізична чи юридична особа має право на будь-якій стадії кримінального провадження відшкодувати шкоду, завдану потерпілому, територіальній громаді, державі внаслідок кримінального правопорушення [9], як загальнокримінального, так і у сфері земельних відносин.

Крім того, відповідно до цієї статті, шкода, завдана кримінальним правопорушенням або іншим суспільно небезпечним діянням, може бути стягнута за судовим рішенням за результатами розгляду цивільного позову в кримінальному провадженні за кошт Державного бюджету України у випадках і в порядку, передбачених законом.

Порядок пред’явлення цивільного позову у кримінальному провадженні передбачений ст. 128 КПК України, яким визначено, що особа, якій кримінальним правопорушенням або іншим суспільно небезпечним діянням завдано майнової та/або моральної шкоди, має право під час кримінального провадження до початку судового розгляду пред'явити цивільний позов до підозрюваного, обвинуваченого або до фізичної чи юридичної особи, що за законом несе цивільну відповідальність за шкоду, завдану діяннями підозрюваного, обвинуваченого або неосудної особи, яка вчинила суспільно небезпечне діяння. 
Висновки. Якщо кримінальним правопорушенням завдано збитків, якими спричинено шкоду інтересам неповнолітніх осіб та осіб, визнаних у встановленому законом порядку недієздатними чи обмежено дієздатними, цивільний позов може бути пред'явлений їхніми законними представниками. У разі завдання неправомірними діями збитків інтересам держави цивільний позов у кримінальному провадженні подається та підтримується прокурором.

Прокурор, який пред’являє цивільний позов у кримінальному провадженні, повинен обгрунтувати наявність підстав для здійснення представництва інтересів громадянина або держави в суді, передбачених ч. 4 ст. 23 Закону України «Про прокуратуру» [7].

Для представництва інтересів громадянина в суді прокурор також повинен надати документи, що підтверджують недосягнення повноліття, недієздатність або обмежену дієздатність відповідного громадянина, а також письмову згоду законного представника або органу, якому законом надано право захищати права, свободи та інтереси відповідної особи, на здійснення ним представництва.

\section{Список використаних джерел:}

1.Азаров Ю.І., Письменний Д.П., Хабло О.Ю. Відшкодування шкоди потерпілому у кримінальному провадженні за кошт держави. URL: file:///C:/Users/Dellv/Downloads/jnn_2014_5_6\% 20(1).pdf.

2.Атанесян Г.А., Голубятников С.П. Судебная бухгалтерия. Москва : Высшая школа, 1989. 324 c.

3.Безлепкин Б.Т. Возмещение вреда, причиненного гражданину судебно-следственными органами : учеб. пособие. Москва, 1979. 204 с.

4.Герасимчук О.П. Визнання особи потерпілою від злочину. Університетські наукові записки. 2007. № 1. С. 210.

5.Гошовський М.І., Кучинська О.П. Потерпілий у кримінальному процесі України. Київ : Юрінком Інтер, 1998.192 с.

6.Европейская конвенция по возмещению ущерба жертвам насильственных преступлений от 24 ноября 1983 г. / База даних «Законодавство України» / BP України URL: http://zakon4. rada.gov.ua/laws/show/994_319.

7.Закон України «Про прокуратуру» / Відомості Верховної Ради (ВВР). 2015. № 2-3, Ст. 12 / База даних «Законодавство України» / BP України. URL: http://zakon5.rada.gov.ua/laws/ show/1697-18. $203 \mathrm{c}$.

8.Ковалев М.И. Понятие преступления в советском уголовном праве. Свердловск, 1987.

9.Кримінальний процесуальний кодекс України : Закон України від 13 квітня 2012 р. № 4651-VI / База даних «Законодавство Украӥни» / ВP України. URL: http://zakon2.rada.gov.ua/ laws/show/-4651\%D0\%B017/print1329- 93292447164.

10. Нор В.Т. Інститут відшкодування (компенсація) шкоди у кримінальному провадженні за новим КПК України: здобутки і резерви для вдосконалення. Право України. 2013. № 11. С. 41. 